Copyright by the Ecological Society of America. Jennifer L. Tank and J. R. Webster 1998. INTERACTION OF SUBSTRATE AND NUTRIENT AVAILABILITY ON WOOD BIOFILM PROCESSES IN STREAMS. Ecology 79:2168-2179. http:// $\mathrm{dx}$.doi.org/10.1890/0012-9658(1998)079[2168:IOSANA] 2.0.CO;2

Ecology, 79(6), 1998, pp. 2168-2179

(C) 1998 by the Ecological Society of America

\title{
INTERACTION OF SUBSTRATE AND NUTRIENT AVAILABILITY ON WOOD BIOFILM PROCESSES IN STREAMS
}

\author{
JenNifer L. TANK AND J. R. Webster \\ Department of Biology, Virginia Polytechnic Institute \& State University, Blacksburg, Virginia 24061 USA
}

\begin{abstract}
We examined the effect of decomposing leaf litter and dissolved inorganic nutrients on the heterotrophic biofilm of submerged wood in streams with and without leaves. Leaf litter was excluded from one headwater stream in August 1993 at Coweeta Hydrologic Laboratory in the southern Appalachian Mountains. We compared microbial processes on wood in the litter-excluded stream to a reference stream using microbial respiration, fungal biomass, and extracellular enzyme activity. Exclusion of leaf litter enhanced microbial respiration and extracellular enzyme activity, and fungal biomass was seven times higher than in the reference stream. Nutrient-releasing substrates placed beneath wood veneers indicated colimitation by nitrogen and phosphorus on biofilms in the reference stream. Our conclusion is that, in the absence of nutrient immobilization by leaves, nutrients are more available for other heterotrophic processes. Nutrient limitation may have been responsible for low microbial respiration, fungal biomass, and extracellular enzyme activity on wood in the reference stream containing leaves. Our results suggest that competition for nutrients may regulate heterotrophic microbial processes in these streams.
\end{abstract}

Key words: decomposition; enzyme activity; ergosterol; fungal biomass; leaf litter; microbial respiration; nitrogen; nutrient; phosphorus; stream; wood biofilms.

\section{INTRODUCTION}

Primary production in many ecosystems is limited by availability of inorganic nutrients. In fact, this is a common situation in freshwater systems (e.g., Schindler 1977, Elwood et al. 1981, Wetzel 1983, Peterson et al. 1985, Grimm and Fisher 1986, Pringle 1987, Peterson et al. 1993, Rosemond et al. 1993). Heterotrophic organisms in systems dominated by autochthonous production can also be limited by nutrients; bacterioplankton production was shown to be phosphorus limited in lakes (Morris and Lewis 1992). But in heterotrophic ecosystems, such as forest streams and the deep ocean, where autotrophic production is low and ecosystem production is based primarily on allochthonous inputs, competition for nutrients and regulation of production by inorganic nutrients is less common because heterotrophic organisms are limited first by organic carbon. Decomposing organic matter may be deficient in elements such as nitrogen or phosphorus, thus dictating the need for an external supply of inorganic nutrients to support heterotrophic production. In forest streams where leaves and wood are the major sources of organic matter available to heterotrophic microbes, it appears that these materials are often deficient in nutrients. Wood is more deficient in nutrients than are leaves, with lignin to nitrogen ratios in wood ranging from 42 to 647 (Melillo et al. 1983). Heterotrophic microbes that degrade leaves and wood must

Manuscript received 19 February 1997; revised 19 September 1997; accepted 23 September 1997. obtain needed inorganic nutrients from the water column.

A variety of studies suggest that leaf breakdown in streams is related to water column nutrient concentrations, thus creating the potential for heterotrophic microbes to compete for nutrients. Laboratory studies have consistently shown that nutrient addition can stimulate microbial activity, biomass, and leaf breakdown in streams (e.g., Hynes and Kaushik 1969, Howarth and Fisher 1976). In situ stream studies have had variable results. Triska and Sedell (1976) found that nitrate had no effect on the decomposition rates of four species of leaf litter in a Cascade Mountain stream. Evidence for nitrogen stimulation of leaf decomposition was found in a comparison of two North Carolina streams differing in nitrate concentrations (Meyer and Johnson 1983). In Walker Branch, Tennessee, phosphorus addition was shown to increase leaf decomposition (Elwood et al. 1981), yet nitrogen addition to the same stream had no effect on decomposition rates (Newbold et al. 1983). Experiments in this same stream by Mulholland et al. $(1984,1985)$ showed that phosphate uptake is greatest during November, when leaf litter is more abundant, suggesting that microbes colonizing organic matter use nutrients from the water column. Fungal biomass, production, sporulation rates, and leaf breakdown rates were highest in Alabama streams with the highest concentrations of nutrients (Suberkropp 1995, Suberkropp and Chauvet 1995). Taken together, these studies suggest that heterotrophic microorganisms colonizing various stream substrates may be nutrient limited. 
Most studies of organic matter dynamics in streams have focused on the role of leaves rather than wood because leaves normally make up the bulk of organic matter inputs to small forested streams. Leaves can be considered a seasonal resource, since they enter temperate streams as a pulse during autumn leaf fall and decompose within 4-8 mo (Webster and Benfield 1986). In contrast to leaves, wood is a long-lasting organic matter resource that may take years to decompose (e.g., Harmon et al. 1986). At certain times of the year (e.g., summer), wood standing stocks in small headwater streams at Coweeta can account for $>50 \%$ of all organic matter present (Tank et al. 1993). Surface area estimates for small woody debris $(<5 \mathrm{~cm}$ diameter) per unit area of streambed ranged from 0.6 to 0.8 $\mathrm{m}^{2}$ of wood per square meter in our study streams ( $\mathrm{J}$. B. Wallace, University of Georgia, Athens, Georgia, unpublished data).

Our research was part of a whole-stream manipulation begun in August 1993 in which inputs of leaf litter were excluded from a headwater stream draining a forested watershed at Coweeta Hydrologic Laboratory, North Carolina. As a result of leaf litter exclusion, wood is the sole source of large particulate organic matter. Hence the heterotrophic food chain, once dependent on leaf litter inputs, microbial colonization of litter, and consumption of that litter by shredding insects, has shifted to one based on the microbial colonization of woody debris. How does this shift in the base of the heterotrophic food chain affect factors controlling organic matter processes?

The objectives of our study were to determine whether the presence of decomposing leaf litter affects microbial processes of biofilms colonizing wood in streams. Microbial respiration, fungal biomass, and extracellular enzyme activity on wood were used to compare the biofilm between the litter exclusion and reference stream. We propose that the mechanism by which leaf litter affects heterotrophic biofilms on wood is through the immobilization of dissolved inorganic nutrients from the streamwater, reducing their availability to wood-associated biofilms. Nutrient-releasing substrates covered by wooden disks were used to determine whether wood biofilms were limited by the availability of nutrients. Additionally, we identified differences in dissolved nutrient distribution between streams using short-term releases of a conservative tracer to identify sources of high-nutrient groundwater.

\section{Methods}

\section{Site description}

We studied two first-order streams draining Watersheds 53 and 55 at Coweeta Hydrologic Laboratory, Macon County, North Carolina, USA. Coweeta is a 2270-ha experimental forest of the U.S. Forest Service located in the southern Appalachians. The forest canopy is dominated by yellow poplar (Liriodendron tu-
TABle 1. Physical and chemical characteristics of the two study streams. Values are annual means since 1985 (J. B. Wallace, University of Georgia, Athens, Georgia, unpublished data).

\begin{tabular}{lcc}
\hline \hline \multicolumn{1}{c}{ Variable $\dagger$} & Watershed & Watershed \\
& 53 & 55 \\
\hline Temperature $\left({ }^{\circ} \mathrm{C}\right)$ & 12.3 & 12.2 \\
Elevation $(\mathrm{m}$ a.s.l.) at flume & 820 & 810 \\
Catchment area $(\mathrm{ha})$ & 5.2 & 7.5 \\
Average discharge $(\mathrm{L} / \mathrm{s})$ & 1.06 & 1.72 \\
Maximum discharge $(\mathrm{L} / \mathrm{s})$ & 30.3 & 46.9 \\
$\mathrm{pH}$ & 6.8 & 6.7 \\
$\mathrm{NO}{ }_{3}-\mathrm{N}(\mu \mathrm{g} / \mathrm{L})$ & 8 & 10 \\
$\mathrm{NH}_{4}-\mathrm{N}(\mu \mathrm{g} / \mathrm{L})$ & 2 & 3 \\
$\mathrm{TKN}(\mu \mathrm{g} / \mathrm{L})$ & 30 & 28 \\
$\mathrm{SRP}(\mu \mathrm{L})$ & 3 & 1 \\
$\mathrm{Cl}(\mathrm{mg} / \mathrm{L})$ & 0.538 & 0.656 \\
$\mathrm{~K}(\mathrm{mg} / \mathrm{L})$ & 0.441 & 0.397 \\
$\mathrm{Na}(\mathrm{mg} / \mathrm{L})$ & 1.060 & 0.777 \\
$\mathrm{Ca}(\mathrm{mg} / \mathrm{L})$ & 0.599 & 0.468 \\
$\mathrm{Mg}(\mathrm{mg} / \mathrm{L})_{\mathrm{SO}_{4}(\mathrm{mg} / \mathrm{L})}$ & 0.423 & 0.371 \\
$\mathrm{SiO}_{2}(\mathrm{mg} / \mathrm{L})$ & 0.357 & 0.399 \\
$\mathrm{HCO}_{3}\left(\mathrm{mg} / \mathrm{L}\right.$ as $\left.\mathrm{CaCO}_{3}\right)$ & 8.015 & 6.812 \\
\hline
\end{tabular}

$\dagger \mathrm{TKN}=$ total Kjeldahl nitrogen, $\mathrm{SRP}=$ soluble reactive phosphorus.

lipifera), white oak (Quercus alba), red oak (Quercus rubra), and dogwood (Cornus florida). There is also a dense understory of rhododendron (Rhododendron maxima), which results in year-round shading and low rates of primary productivity (Wallace et al. 1997a) in the study streams. Both study streams have similar water chemistry, with low dissolved nutrient concentrations and $\mathrm{pH}$ between 6.7 and 6.8, southern aspect, and similar thermal regimes (Table 1). Both streams are groundwater fed and therefore are cool in summer and do not freeze in winter $\left(2^{\circ}-17^{\circ} \mathrm{C}\right)$. Streambed substrata consist of mixed cobble-pebble with sand-gravel and some bedrock outcrops (14-27\%; J. B. Wallace, unpublished data).

As part of the larger experiment, leaf litter inputs have been excluded along the length of stream $(180 \mathrm{~m})$ draining Watershed 55 since August 1993 by placing a $1.5-\mathrm{cm}$ mesh canopy over the stream (Wallace et al. $1997 b$ ). The canopy was positioned beneath the natural rhododendron understory to maintain the normal heavy shade and yet continue to exclude rhododendron leaves ( $27 \%$ of total leaf litter input; Cuffney et al. 1990). Small woody debris $(<5 \mathrm{~cm})$ and leaf litter made up most of the standing crop of benthic organic matter before leaf exclusion (60-65 and 20-24\%, respective1y). Surface area of small woody debris made up a considerable proportion of colonizable organic substrate in the reference stream and wood was the only large organic substrate left for microbial colonization after leaf exclusion (Table 2).

\section{Sample arrays}

Untreated wood strips constructed from wood veneer $(2.5 \mathrm{~cm} \times 15 \mathrm{~cm} \times 1 \mathrm{~mm})$ of yellow poplar and white 
TABLE 2. Wood standing stocks in wetted perimeter of study streams for two years. Values are annual means, and standard errors are presented in parentheses.

\begin{tabular}{|c|c|c|}
\hline Year & Reference stream & Exclusion stream \\
\hline \multicolumn{3}{|l|}{1994} \\
\hline Wood surface area $\left(\mathrm{m}^{2} / \mathrm{m}^{2}\right)$ & $0.864(0.208)$ & $1.212(0.156)$ \\
\hline Wood biomass $\left(\mathrm{kg} / \mathrm{m}^{2}\right)$ & $7.4 \quad(2.6)$ & $11.5 \quad(3.7)$ \\
\hline Leaf biomass (g AFDM $/ \mathrm{m}^{2}$ ) & $276.1 \quad(34.7)$ & $26.5 \quad(9.90)$ \\
\hline \multicolumn{3}{|l|}{1995} \\
\hline Wood surface area $\left(\mathrm{m}^{2} / \mathrm{m}^{2}\right)$ & $1.098(0.257)$ & $0.967(0.175)$ \\
\hline Wood biomass $\left(\mathrm{kg} / \mathrm{m}^{2}\right)$ & $13.8 \quad(5.5)$ & $8.9 \quad(2.4)$ \\
\hline Leaf biomass (g AFDM/m²) & $290.6 \quad(32.3)$ & $0.68 \quad(0.35)$ \\
\hline
\end{tabular}

Note: Wood surface area is expressed as square meter of wood per square meter of streambed, whereas biomass estimates are presented as kilograms per square meter of streambed for wood and grams per square meter of streambed for leaves (J. B. Wallace, University of Georgia, Athens, Georgia, unpublished data). AFDM = ash-free dry mass.

oak were used as substrates for microbial colonization in the study streams. These two wood types were used because both species are present in the riparian forest, and woody debris of both tree species are found in the study streams. Using wood strips (hereafter referred to as sticks) allowed accurate estimation of surface area. Sticks were attached with cable ties to plastic mesh holders with five replicates on each holder. The mesh holders were staked firmly to the stream bed. Long axes of sticks were oriented parallel to the direction of flow.

In experiment 1 , six sets of oak and poplar sticks (5 sticks/set) were placed in each stream during autumn leaffall (24 October 1994). One set per tree species was collected monthly from each stream and returned to the laboratory in containers of cold stream water. Sticks from the exclusion stream were almost completely decomposed by $238 \mathrm{~d}$ and thereafter nothing could be collected. Microbial respiration rates at ambient stream temperature and at $20^{\circ} \mathrm{C}$ and fungal biomass were determined for all sticks.

A second experiment was conducted in spring. In experiment 2, four sets of poplar sticks (5 sticks/set) were placed in each stream on 24 April 1995. One set of sticks was collected monthly from each stream and returned to the laboratory in containers of cold stream water. Additionally, two $60-\mathrm{mL}$ water samples were collected on each date, one from the streamwater passing over the set of collected sticks and one from the flume at the bottom of the experimental reach. Microbial respiration rates at ambient stream temperature and at $20^{\circ} \mathrm{C}$, fungal biomass, and cellobiohydrolase activity were determined in the laboratory. Water samples were analyzed for ammonia, nitrate, and soluble reactive phosphorus (SRP) on a Shimadzu spectrophotometer according to standard methods (APHA 1989).

\section{Microbial respiration and wood breakdown rates}

Respiration rates, as microbial oxygen uptake, were measured on sticks using a Gilson differential respirometer. A subsample from each stick collected from both streams was placed in a $15-\mathrm{mL}$ Gilson flask containing $5 \mathrm{~mL}$ filtered stream water from its respective stream. A filter soaked with potassium hydroxide was placed in the center well of the flask to absorb evolved $\mathrm{CO}_{2}$. Each set of samples was incubated once at ambient stream temperature and once at a constant reference temperature $\left(20^{\circ} \mathrm{C}\right)$. Flasks containing new, uncolonized wood served as controls and confirmed that no abiotic uptake of oxygen had occurred. Sample incubations lasted $2.5-5 \mathrm{~h}$, depending on temperature, and were completed after measurable oxygen uptake occurred. After each incubation, samples were oven dried at $50^{\circ} \mathrm{C}$ for $72 \mathrm{~h}$, weighed, ashed for $90 \mathrm{~min}$ at $550^{\circ} \mathrm{C}$, rewetted to restore water of hydration, dried, and reweighed to obtain ash-free dry mass (AFDM) for each sample. These samples were also used to calculate organic matter breakdown rates.

Respiration rates were calculated using the following formula (Umbreit et al. 1964):

$$
X=\left(\Delta V_{\mathrm{g}}\right) \frac{P-P_{\mathrm{w}}}{P_{1}} \frac{T_{1}}{T}
$$

where $X=$ oxygen uptake (in microliters), $\Delta V_{\mathrm{g}}=$ change in volume of respirometer (in microliters), $P$ $=$ total gas pressure within respirometer (in millimeters of Mercury), $P_{\mathrm{w}}=$ vapor pressure of water at temperature $(T)$ in millimeters of mercury, $P_{1}=$ standard pressure $=760 \mathrm{~mm} \mathrm{Hg}, T_{1}=$ standard temperature $=$ $273.15^{\circ} \mathrm{K}$, and $T=$ temperature of water bath $\left({ }^{\circ} \mathrm{K}\right)$. Respiration rates were expressed both on a surface area and grams AFDM basis.

Breakdown rates $(k)$ of wood were calculated by regressing the natural log of mean percentage AFDM remaining on exposure time. The negative slope of the regression line is equal to the breakdown rate of the substrate (Petersen and Cummins 1974).

\section{Fungal biomass}

Fungal biomass on sticks was estimated by ergosterol content using the method outlined by Newell et al. (1988) and modified by R. L. Sinsabaugh (University of Toledo, Toledo, Ohio, personal communication). Subsamples of known surface area $(2.5 \times 3 \mathrm{~cm})$ were placed in $15-\mathrm{mL}$ Falcon tubes with $5 \mathrm{~mL}$ methanol and 
refluxed in a dry block heater for $2 \mathrm{~h}$ at $65^{\circ} \mathrm{C}$. Tubes were removed from heater, cooled, saponified by adding $1 \mathrm{~mL} \mathrm{4 \%} \mathrm{KOH}$ in methanol, and refluxed for another $0.5 \mathrm{~h}$ at $65^{\circ} \mathrm{C}$. Samples were cooled, centrifuged, and the supernatants were decanted into clean $15-\mathrm{mL}$ Falcon tubes. The pellets were resuspended in $2 \mathrm{~mL}$ HPLC (high pressure liquid chromatography)-grade methanol, centrifuged again, and the rinse methanol was added to the tubes containing the extracts along with $1 \mathrm{~mL}$ water. The supernatants were then extracted two times with $2 \mathrm{~mL}$ pentane. Pentane extracts were combined and evaporated in a fume hood. The residue was redissolved with $1 \mathrm{~mL}$ HPLC-grade methanol and filtered through a $0.45-\mu \mathrm{m}$ syringe filter into clean 5$\mathrm{mL}$ polypropylene tubes. Ergosterol was quantified using a reverse-phase HPLC system configured as follows: solvent $=$ methanol; flow rate $=2 \mathrm{~mL} / \mathrm{min}$; column = Nova-Pak ODS C18 $3.9 \mathrm{~mm} \times 75 \mathrm{~mm}$; absorbance detector $=282 \mathrm{~nm}$ with a range of 0.500 ; quantification $=$ Waters integrator with attenuation at 256; ergosterol retention time $=1.6 \mathrm{~min}$; replication $=5$ per sample; standards $=5,10,25$, and $50 \mu \mathrm{g} / \mathrm{ml}$ solution of ergosterol and methanol. Ergosterol content was converted to fungal biomass using a general conversion factor of $6 \mathrm{mg}$ ergosterol/g fungal biomass (Newell et al. 1988).

\section{Cellulose degradation potential}

Wood biofilms were assayed for the activity of cellobiohydrolase (CBH, EC [Enzyme Commission number] 3.2.1.91), an extracellular enzyme involved in the degradation of lignocellulose, as outlined by Sinsabaugh et al. (1991). Five subsamples $(2.5 \times 3.0 \mathrm{~cm})$ were cut from wood from each stream on each collection date. Biofilm was scraped from each subsample with a razor blade and placed into separate test tubes containing $2 \mathrm{~mL}$ of $50 \mathrm{mmol} / \mathrm{L}$ acetate buffer $(\mathrm{pH}=$ 5). Two milliliters of $2 \mathrm{mmol} / \mathrm{L} \mathrm{p}$. nitrophenyl-cellobioside dissolved in $50 \mathrm{mmol} / \mathrm{L}$ acetate buffer $(\mathrm{pH}=$ 5.0) were added to the tubes, and tubes were capped and incubated on a platelet mixer at $3 \mathrm{rpm}$ at $20^{\circ} \mathrm{C}$ for $4 \mathrm{~h}$. Controls were wood biofilm scrapings suspended in $4 \mathrm{~mL}$ of acetate buffer without enzyme. After incubation, samples were centrifuged, and $2 \mathrm{~mL}$ supernatant were added to test tubes containing $0.2 \mathrm{~mL}$ of $1 \mathrm{~mol} / \mathrm{L} \mathrm{NaOH}$. After adding $8 \mathrm{~mL}$ water, each tube was vortexed, and absorbence at $410 \mathrm{~nm}$ was measured on a spectrophotometer. Activity was expressed as $\mu$ moles of substrate hydrolyzed per hour per square centimeter substrate.

\section{Nutrient-addition assays}

Experiment 3 involved using nutrient-diffusing substrates to determine the effect of nitrate and phosphate additions on the development of epixylic biofilms. The substrates were $60-\mathrm{mL}$ plastic cups filled with $2 \%$ agar to some of which we added nutrients (e.g., Winterbourn 1990). The agar surface was completely covered with a disk $\left(12.5 \mathrm{~cm}^{2}\right)$ of untreated poplar veneer, the diffusion surface on which the biofilm developed. Four treatments were used: Control (agar only), $\mathrm{N}$ addition (0.66 mol/L $\left.\mathrm{NaNO}_{3}\right), \mathrm{P}$ addition $\left(0.51 \mathrm{~mol} / \mathrm{L} \mathrm{KH}_{2} \mathrm{PO}_{4}\right)$, and $\mathrm{N}+\mathrm{P}$ addition $\left(0.66 \mathrm{~mol} / \mathrm{L} \mathrm{NaNO}_{3}+0.06 \mathrm{~mol} /\right.$ $\mathrm{L} \mathrm{KH}_{2} \mathrm{PO}_{4}$ ) (Winterbourn 1990). Five replicate cups of each treatment were glued to a plastic tray, two trays were anchored to stream beds of each stream on 26 August 1995, and trays from each stream were recovered after 29 and 63 d (Tank and Winterbourn 1995). Microbial respiration and fungal biomass on the wood disks were determined for five replicate samples of each treatment from each stream at each collection date as described above.

\section{Identification of groundwater inflow in study streams}

To identify areas of potentially higher nutrient availability associated with groundwater inflow, chloride was used as a conservative tracer of water flow to identify areas of groundwater inflow in the litter exclusion and reference streams (Triska et al. 1989, Stream Solute Workshop 1990, Webster and Ehrman 1996). Stream chloride concentration was increased from $<1.0 \mathrm{mg} / \mathrm{L}$ background to $\sim 20 \mathrm{mg} / \mathrm{L}$ by dripping a $\mathrm{NaCl}$ solution at a constant rate into the streams using a Mariotte bottle (Triska et al. 1989). After the chloride concentration reached plateau $(\sim 1 \mathrm{~h})$, chloride was measured at 5-m intervals in each stream using a chloride-specific probe. A steady decrease in concentration was expected due to a gradual increase in flow over the stream reach, but distinct drops in chloride concentration indicated discrete areas of high groundwater inflow. Three replicate $60-\mathrm{mL}$ water samples were collected from one area of groundwater input and at the flume of the exclusion stream, and samples were analyzed for ammonia, nitrate, and SRP on a Shimadzu spectrophotometer according to standard methods (APHA 1989).

\section{Statistical analyses}

All data were log transformed to normalize the data distribution prior to statistical analysis. Nested analysis of variance (ANOVA) was used to compare respiration rates, ergosterol values, and $\mathrm{CBH}$ activities between streams for different wood types on different sampling dates. Nested ANOVA was also used to compare nutrient treatments in the two streams on different collection dates. Least-squares means (LSM) followed significant ANOVA $(P<0.05)$ to differentiate between means.

\section{RESULTS}

\section{Experiment 1: Autumn-poplar vs. oak wood}

Microbial respiration on poplar and oak sticks incubated at ambient stream temperature (mean = $10.8^{\circ} \mathrm{C}$ ), expressed per unit surface area, was significantly higher in the exclusion stream than in the reference stream on all collection dates (Fig. 1A, nested 


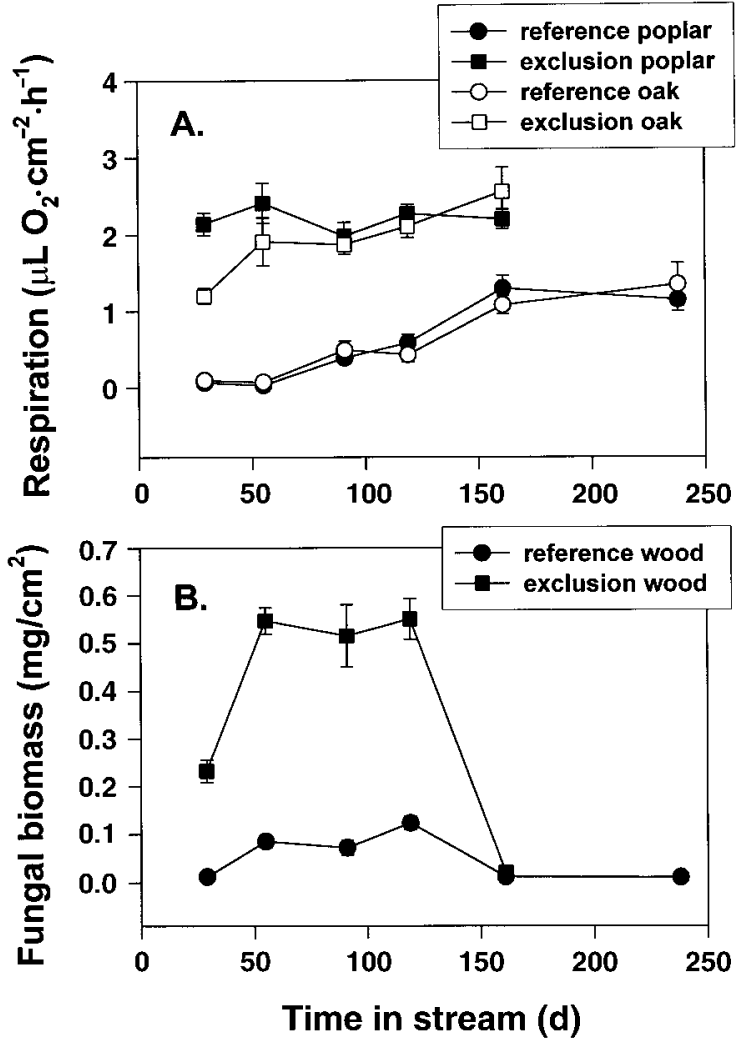

FIG. 1. Microbial respiration (A) and fungal biomass (B) in streams with (reference) and without (exclusion) leaves in experiment 1, begun 24 October 1994. Means $\pm 1 \mathrm{SE}$ are plotted. $N=5$ for each data point in (A) and $N=10$ for each data point in (B).

ANOVA, $P=0.0001)$. Overall, mean respiration $( \pm 1$ $\mathrm{SE})$ at ambient temperature was four times higher in the exclusion stream than in the reference stream $(2.05$ \pm 0.08 and $0.55 \pm 0.07 \mu \mathrm{L} \mathrm{O}_{2} \cdot \mathrm{cm}^{-2} \cdot \mathrm{h}^{-1}$, respectively). Similar trends in respiration, expressed per unit surface area and per gram AFDM, were seen when sticks were incubated at $20^{\circ} \mathrm{C}$. Generally, there were no significant differences in microbial respiration between oak and poplar sticks, except on two dates (days 29 and 55) in the exclusion stream when respiration was significantly higher on poplar (nested ANOVA, LSM, $P=0.0001$ and 0.0397 , respectively).

Fungal biomass was significantly higher in the exclusion stream than in the reference stream on the first four collection dates (Fig. 1B, nested ANOVA, $P=$ 0.0001 ), but unlike respiration rates, fungal biomass dropped significantly by day 161 in the exclusion stream. Fungal biomass was low throughout the 238$\mathrm{d}$ incubation period in the reference stream. Overall, fungal biomass was seven times higher in the exclusion stream as compared to the reference (means $\pm 1 \mathrm{SE}$, $0.37 \pm 0.03$ and $0.05 \pm 0.01 \mathrm{mg} / \mathrm{cm}^{2}$, respectively). There was no significant difference between fungal biomass on oak and poplar sticks in either stream.

\section{Experiment 2: Spring—poplar wood}

In experiment 2, microbial respiration on poplar sticks, incubated at ambient stream temperature (mean $=15.8^{\circ} \mathrm{C}$ ), expressed per unit surface area, was again significantly higher in the exclusion stream than in the reference stream on all collection dates (e.g., Fig. 2A, nested ANOVA, $P=0.0016)$. Similar results were obtained when sticks were incubated at $20^{\circ} \mathrm{C}$, both when respiration was expressed per unit surface area or per gram AFDM. Mean respiration on poplar sticks at ambient temperature averaged over all collection dates was $3.45 \pm 0.18 \mu \mathrm{L} \mathrm{O} \mathrm{O}_{2} \cdot \mathrm{cm}^{-2} \cdot \mathrm{h}^{-1}$ in the exclusion stream and $2.35 \pm 0.18 \mu \mathrm{L} \mathrm{O}_{2} \cdot \mathrm{cm}^{-2} \cdot \mathrm{h}^{-1}$ in the reference stream.

During experiment 2, fungal biomass on poplar sticks in both streams was highly variable, and no clear trends were discernible (Fig. 2B). The activity of cellobiohydrolase $(\mathrm{CBH})$, an extracellular enzyme, was used as a measure of cellulose-degrading potential. $\mathrm{CBH}$ activity on poplar sticks was significantly higher in the exclusion stream than in the reference stream on days 30, 61, and 89 (nested ANOVA, LSM, $P=$ $0.0001,0.0136$, and 0.0057 , respectively), but by day 126 activity on sticks had decreased in the exclusion
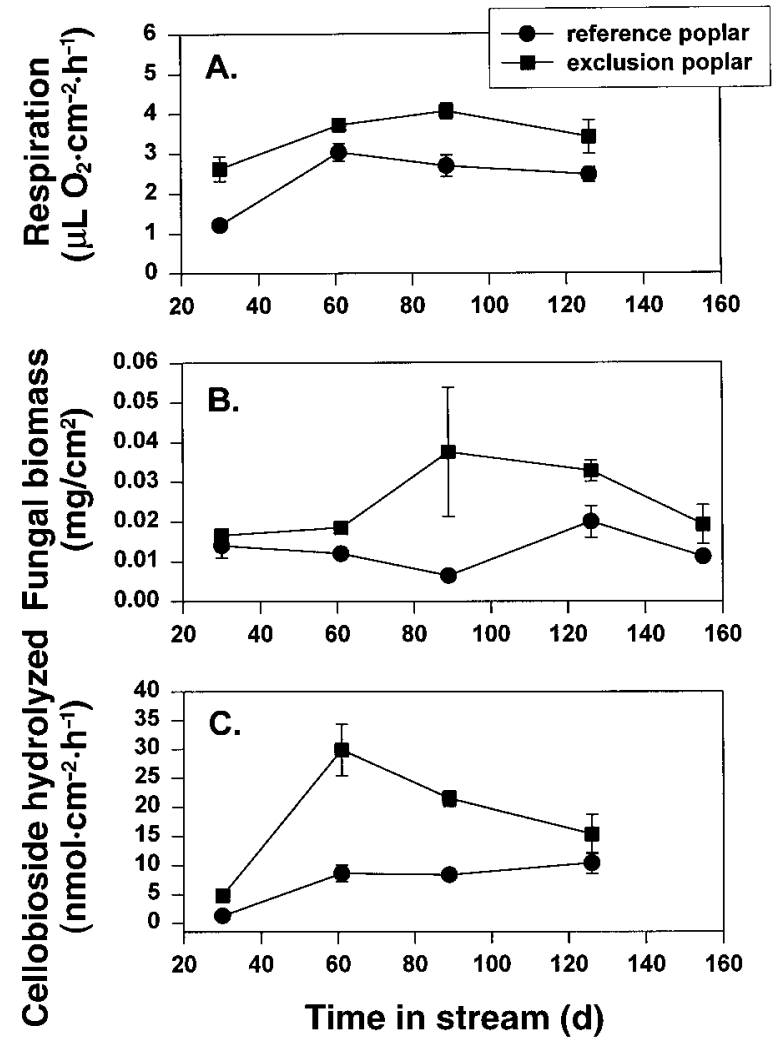

FIG. 2. Microbial respiration (A), fungal biomass (B), and cellulose-degrading potential (C) in streams with (reference) and without (exclusion) leaves in experiment 2, begun 24 April 1995. Means $\pm 1 \mathrm{SE}$ are plotted. $N=5$ for each data point. 


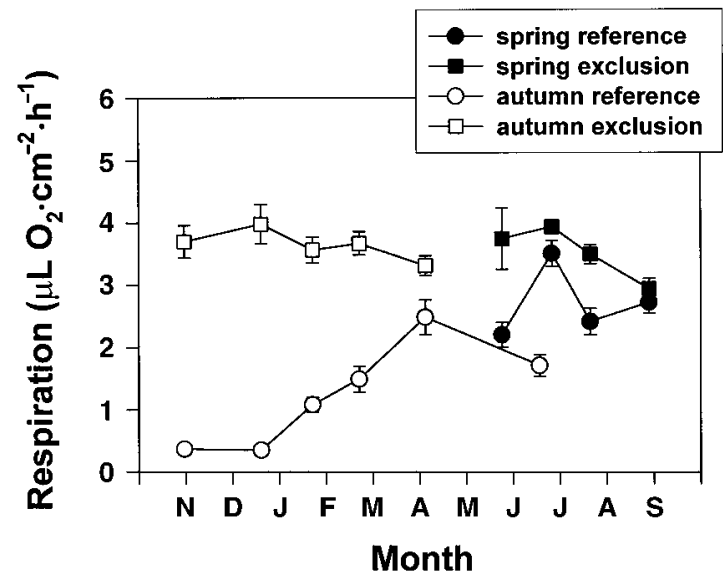

FIG. 3. Seasonal trends in microbial respiration on poplar veneers in streams with and without leaves (incubated at $20^{\circ} \mathrm{C}$ ). Means $\pm 1 \mathrm{SE}$ are plotted. $N=5$ for each data point

stream and increased in the reference stream, resulting in no significant differences in $\mathrm{CBH}$ activity (Fig. 2C).

\section{Seasonal trends in microbial colonization: Autumn vs. spring incubations}

Microbial respiration (per unit surface area) on poplar sticks was compared between the autumn (experiment 1 ) and the spring (experiment 2). Respiration data from the $20^{\circ} \mathrm{C}$ Gilson incubations were used in order to eliminate the effects of seasonal differences in water temperature on microbial respiration. Respiration rates in the exclusion stream during autumn and spring were not significantly different (Fig. 3, nested ANOVA, LSM, $P=0.7704)$. In contrast, respiration rates in the reference stream were significantly higher in spring than in autumn (nested ANOVA, LSM, $P=0.0001$ ). In fact, spring respiration rates in the reference stream were as high as autumn respiration rates in the exclusion stream.

Fungal biomass on poplar sticks in the exclusion stream during autumn was an order of magnitude higher than in spring (Figs. 1B and 2B, nested ANOVA, LSM, $P=0.0001)$. Fungal biomass was very low in the reference stream during both experiments, but values were still slightly higher in autumn (nested ANOVA, LSM, $P=0.001)$.

\section{Decomposition rates}

During experiment 1, the autumn study, both oak and poplar lost mass over the study period in the exclusion stream, but neither wood type lost mass in the reference stream (Fig. 4A). Decomposition rates, $k$, were $0.00146 \mathrm{~d}^{-1}$ for oak and $0.00401 \mathrm{~d}^{-1}$ for poplar sticks in the exclusion stream. Decomposition rates were not calculated for the reference stream. In contrast, for experiment 2 , the spring study, poplar sticks in both streams lost mass over time, and decomposition of sticks in the exclusion stream $\left(k=0.0085 \mathrm{~d}^{-1}\right)$ was faster than in the reference stream $\left(k=0.00476 \mathrm{~d}^{-1}\right)$ (ANCOVA, $P=0.0115$ ) (Fig. 4B). Poplar sticks decomposed faster in April than in October.

During decomposition, microbial biomass accumulates during substrate degradation. The ratio of fungal biomass to wood mass changed over time and varied with season. In Experiment 1, begun in autumn, the ratio of fungal biomass to wood mass was higher in the exclusion stream than the reference through day 161 (Fig. 5A). Thereafter, the integrity of wood incubated in the exclusion stream decreased dramatically due to decomposition, and fungal biomass dropped as well. In experiment 2, as time in the stream increased, fungal biomass : substrate mass ratios in the exclusion stream were much higher than in the reference stream (Fig. 5B). In general, ratios of fungal biomass to wood mass in the exclusion stream were higher in autumn than in spring, but there were no seasonal differences in ratios in the reference stream.

\section{Nutrient-releasing substrates}

In experiment 3 , we tested the effect of nutrient enrichments on wood biofilms in both streams using wood disks placed on top of nutrient-releasing substrates. After 29 d, nutrient enrichments had no significant effects on microbial respiration or fungal biomass either within or between streams. After $63 \mathrm{~d}$, in both streams, $\mathrm{N}+$

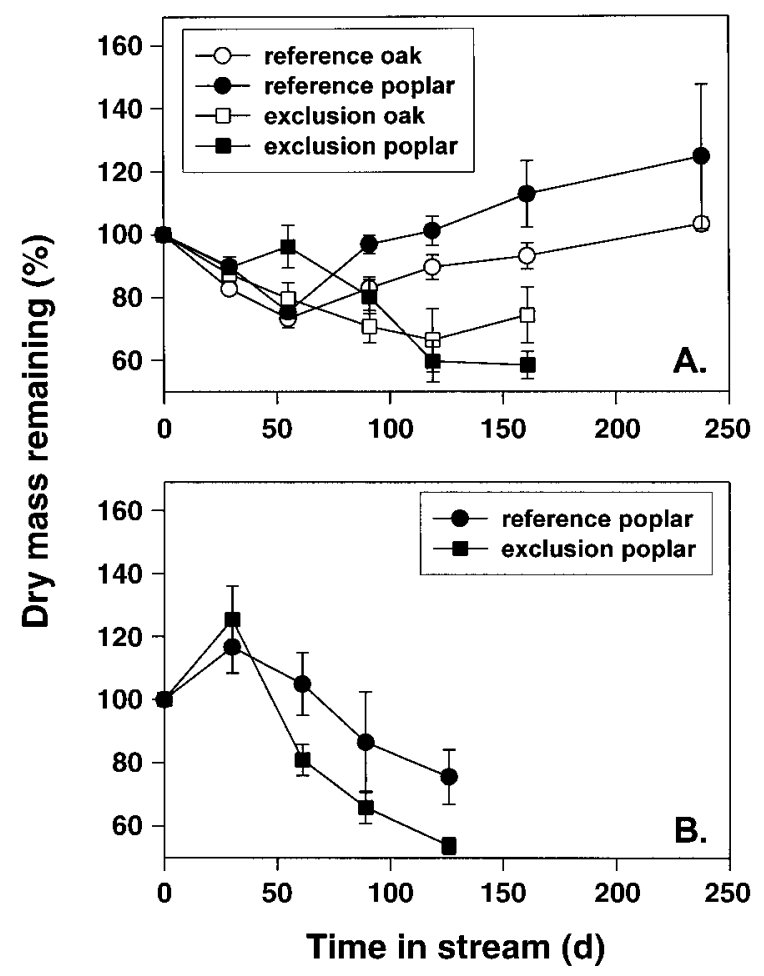

FIG. 4. Substrate mass loss for (A) experiment 1 (begun 24 October 1994) and (B) experiment 2 (begun 24 April 1995) in streams with and without leaves. Means $\pm 1 \mathrm{SE}$ are plotted. $N=5$ for each data point. 

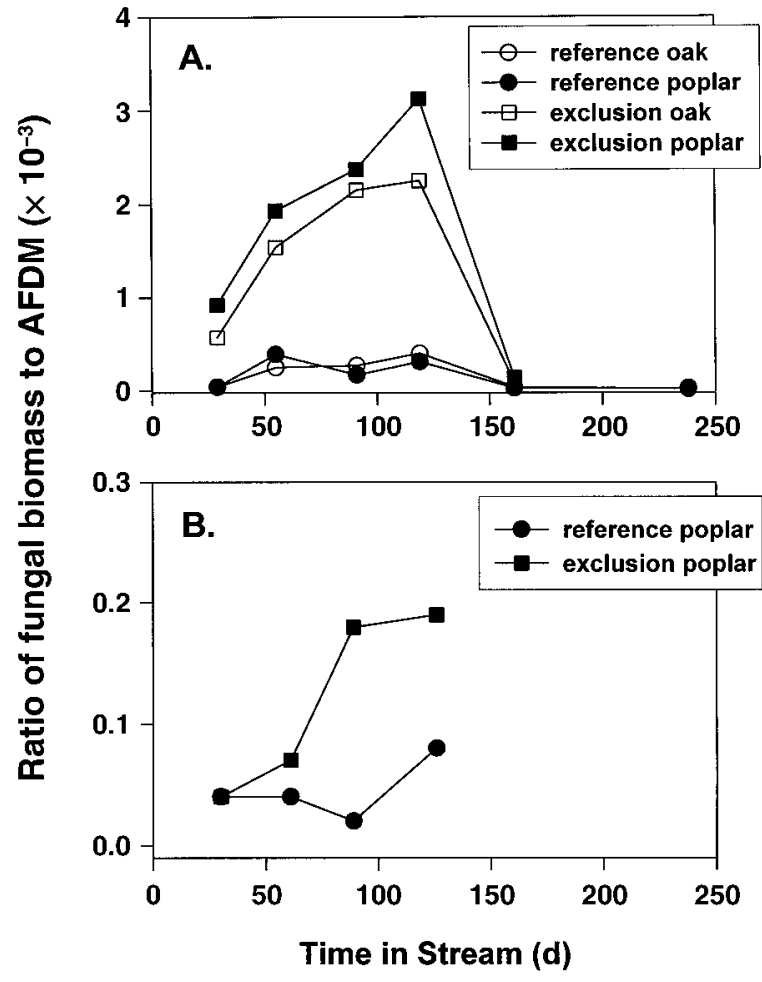

FIG. 5. Ratio of mean fungal biomass to mean AFDM for (A) experiment 1 (begun 24 October 1994) and (B) experiment 2 (begun 24 April 1995) in streams with and without leaves. $N=5$ for each data point.

$\mathrm{P}$ enrichments significantly increased both respiration and fungal biomass (Fig. 6, LSM, $P<0.05$ ). Enrichment with just $\mathrm{N}$ or $\mathrm{P}$ significantly increased respiration only in the reference stream (Fig. 6A, LSM, $P<0.05$ ). Neither $\mathrm{N}$ nor $\mathrm{P}$ enrichment alone significantly increased fungal biomass in either stream (Fig. 6B, $P>$ $0.05)$. There were no significant differences in fungal biomass between streams for any treatment (Fig. 6B). However, wood disks in the exclusion stream had significantly higher respiration rates than wood disks in the reference stream for controls, $\mathrm{N}$, and $\mathrm{P}$ enrichments (Fig. 6A, LSM, $P=0.0001,0.0018$, and 0.0063 respectively), yet there were no significant differences in respiration rates in the $\mathrm{N}+\mathrm{P}$ enrichment (Fig. 6A, LSM, $P=0.3540)$.

\section{Groundwater inflow identification}

The chloride concentration at plateau was plotted against distance from the injection site for both the exclusion and reference streams (Fig. 7), and locations where distinct drops in chloride concentration occurred were identified as areas of groundwater inputs (four in the exclusion stream and three in the reference stream). Mean dissolved nutrient concentrations (ammonia, nitrate, and SRP) from the groundwater input sites in the exclusion stream were generally higher than background levels measured at the flume (ammonia $=19$ vs. $3 \mu \mathrm{g} / \mathrm{L}$, nitrate $=17$ vs. $10 \mu \mathrm{g} / \mathrm{L}$, and SRP $=17$ vs. $1 \mu \mathrm{g} / \mathrm{L})$. In addition, dissolved nutrient concentrations from the monthly water samples taken at the wood incubation sites were compared to nutrient concentrations measured at the flume in both streams. Mean nutrient concentrations from the four monthly collections tended to be higher at wood incubation sites than at the flume in both the exclusion stream (ammonia $=8.6$ vs. $1.1 \mu \mathrm{g} / \mathrm{L}$, nitrate $=23.6$ vs. $11.9 \mu \mathrm{g} / \mathrm{L}$, and SRP $=3.8$ vs. $1.3 \mu \mathrm{g} / \mathrm{L}$ ) and in the reference stream (ammonia $=6.7$ vs. $1.7 \mu \mathrm{g} / \mathrm{L}$, nitrate $=14.5$ vs. $3.1 \mu \mathrm{g} /$ $\mathrm{L}$, and $\mathrm{SRP}=4.6$ vs. $3.1 \mu \mathrm{g} / \mathrm{L})$.

\section{DISCUSSION}

\section{Effect of leaf exclusion on wood microbial biofilms}

Microbial respiration rates and fungal biomass were much higher in the litter exclusion stream than in the reference stream, however, the differences were much greater in experiment 1 compared to experiment 2 . Experiments 1 and 2 were conducted during two different seasons. In autumn, leaf litter is the predominant organic matter source in Appalachian mountain streams.
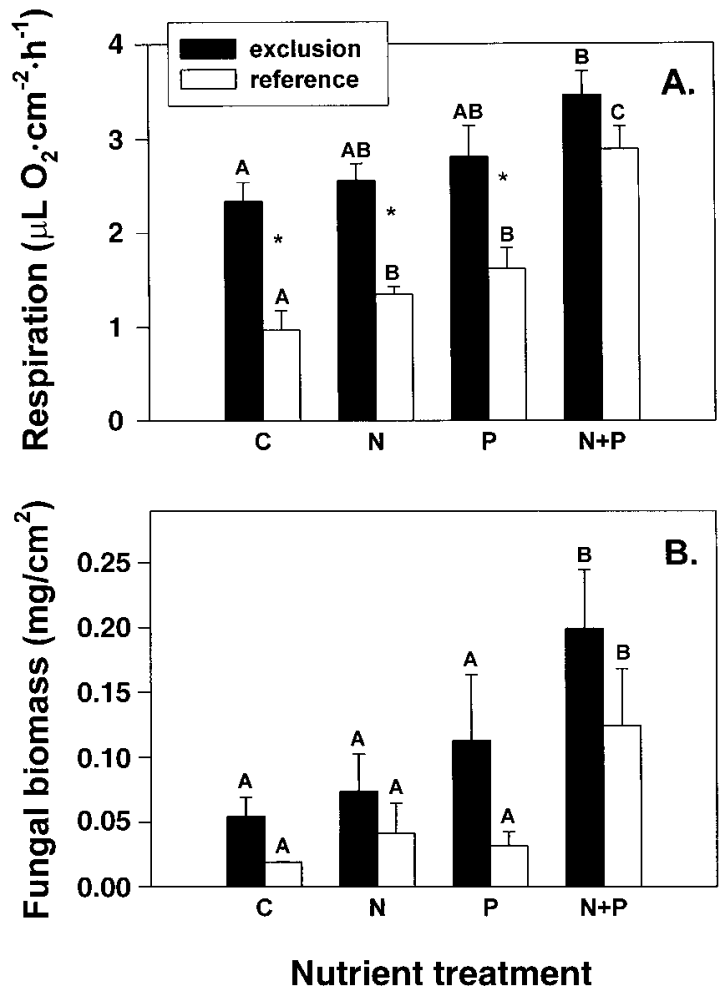

FIG. 6. Effect of nutrient addition on (A) microbial respiration and (B) fungal biomass on poplar disks incubated for $63 \mathrm{~d}$ in streams with and without leaves. $\mathrm{C}=$ control, $\mathrm{N}$ $=\mathrm{NO}_{3}$ added, $\mathrm{P}=\mathrm{PO}_{4}$ added, and $\mathrm{N}+\mathrm{P}=\mathrm{NO}_{3}$ and $\mathrm{PO}_{4}$ added. Means $\pm 1 \mathrm{SE}$ are plotted. $N=5$ for each bar. Letters refer to comparisons of treatments within streams. Bars with same letters were not significantly different (LSM, $P>0.05$ ). Asterisks indicate significant differences between streams for a particular treatment (LSM, $P<0.05)$. 


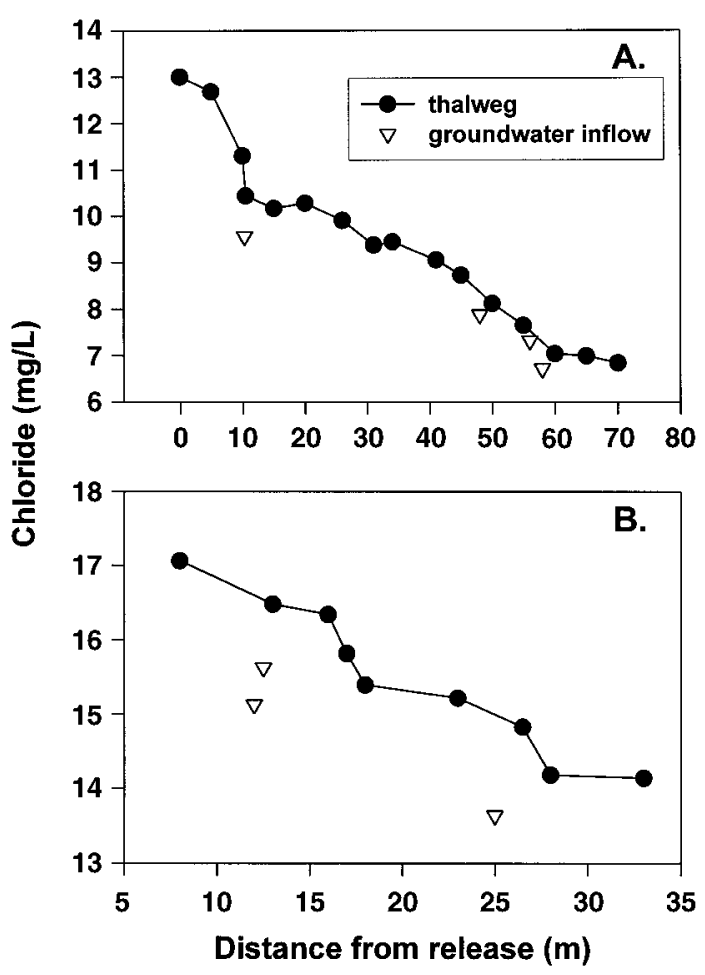

FIG. 7. Identification of groundwater inflow for (A) the leaf exclusion stream and (B) the reference stream. Filled circles $(\bigcirc)$ represent samples from thalweg, and triangles $(\nabla)$ represent samples from areas of groundwater inflow.

In spring, most leaf litter has decomposed and wood is the primary particulate organic matter substrate for heterotrophic microbial colonization. Respiration rates on wood in the reference stream in autumn were significantly lower than in spring. In contrast, microbial respiration rates in the litter exclusion stream did not differ significantly between autumn and spring. Seasonal differences in respiration in the reference stream suggest that not just stream temperature, but also the lower biomass of decaying leaves may have affected microbial activity on wood.

Seasonal trends in fungal biomass were different than those for microbial respiration. Fungal biomass in both streams was lower in spring compared to autumn by almost an order of magnitude. Temperature is known to affect fungal colonization. Suberkropp (1984) identified two major patterns in the structure and function of fungal communities: a summer assemblage, which grows between $5^{\circ}$ and $40^{\circ} \mathrm{C}$ with an optimum of $25^{\circ}$ $30^{\circ} \mathrm{C}$ and a winter assemblage, which grows between $1^{\circ}$ and $30^{\circ} \mathrm{C}$ with an optimum of $20^{\circ} \mathrm{C}$. Our study streams are groundwater-fed headwater streams, showing temperature regimes conducive for year-round dominance of a winter assemblage. For this reason, decreases in fungal biomass from autumn to spring may not be a result of shifts in community structure that are linked to temperature optima. Alternatively, fungal biomass may have declined as a result of an increased proportion of resources being allocated to conidial production at the expense of hyphal growth (e.g., Baldy et al. 1995). As these reproductive structures are entrained in the water column, their biomass would not be included in our measurements of fungal biomass. Our study was limited to general assays of fungal biomass (ergosterol) and further study of fungal community species composition and seasonal trends in fungal and bacterial biomass on wood in headwater streams would clarify the interaction between fungi and bacteria.

\section{Effect of wood type on microbial biofilms}

The effect of litter exclusion on microbial biofilms was the same for the two wood types we tested. There were no significant differences in microbial respiration and fungal biomass between oak and poplar sticks. These results imply that the two wood types used in this study provide similar colonization substrates for microbes. In the only other study to compare microbial colonization on different wood types, Shearer and Von Bodman (1983) monitored fungal colonization on twigs from cherry, oak, silver maple, and sycamore trees that were placed in an Illinois stream for 30 mo. There were no differences in colonization among wood types, and of the 33 species of ascomycetes collected, four species were dominant colonizers. In our study, we were unable to culture any fungi in the laboratory and therefore could not identify them. If there is no specificity in species composition by wood type, functional properties such as respiration rates and fungal biomass may also remain nonspecific. Although overall microbial activity may be similar between wood types, microbial colonization seems to be initially sensitive to differences between oak and poplar sticks. On the first two collection dates (days 29 and 55) poplar had significantly higher respiration rates, but by day 55 there were no differences between wood types.

In contrast to the lack of difference in respiration rates on different wood types, there were significant differences in breakdown rates in the exclusion stream: poplar sticks decomposed faster than oak (Fig. 4A). Faster breakdown of poplar may have been a result of a lower lignin : nitrogen ratio than for oak (Melillo et al. 1983). Melillo et al. (1983) found that chemically labile wood types (i.e., low percentage lignin, low lignin : nitrogen ratio) had faster decomposition rates. Additionally, wood decomposition is strongly influenced by surface area : volume ratios, which in turn influences oxygen diffusion rates and sediment accumulation (Triska and Cromack 1980, Aumen et al. 1983, Golladay and Webster 1988). Wood strips used in this study were very thin $(\sim 1 \mathrm{~mm})$ and therefore had very high surface area : volume ratios. Our breakdown rates were faster $\left(0.0015-0.0085 \mathrm{~d}^{-1}\right)$ than those reported by Melillo et al. (1983) for wood chips from a variety of species (0.0007-0.0033 $\left.\mathrm{d}^{-1}\right)$, Golladay and Webster 
(1988) for small woody debris in Coweeta streams (0.0004-0.0008 $\left.\mathrm{d}^{-1}\right)$, and Golladay and Sinsabaugh (1991) for birch ice cream sticks (0.0016-0.0019 $\left.\mathrm{d}^{-1}\right)$.

The fact that microbial respiration between oak and poplar did not differ, but breakdown rates did, suggests that respiration is a surface phenomenon. Through the time period studied (before sticks fragmented), the biofilm was not limited by substrate availability (i.e., carbon). Thus, while the wood was losing mass, but had not yet started to fragment, microbial respiration expressed on a surface area basis remained constant.

\section{Microbial assays as indicators of ecosystem function}

Four aspects of microbial colonization were used to estimate the impact of litter exclusion on microbial colonization of wood: three were activity-based measures (microbial respiration, $\mathrm{CBH}$ activity, and decomposition rates) and one was a biomass indicator (ergosterol). The biomass measure used in this study estimated only the fungal component of the microbial community-bacterial biomass was not measured. Studies on leaves have indicated that fungi accounted for $>90 \%$ of total microbial biomass in temperate streams (Findlay and Arsuffi 1989, Baldy et al. 1995). Scanning electron micrographs of wood biofilms have shown that microbial colonization on wood is also primarily fungal (Tank and Winterbourn 1995, 1996). Preliminary bacterial counts using acridine orange were conducted in the present study and very few bacterial cells were seen. In the exclusion stream, microbial respiration was similar in the October and April experiments, yet fungal biomass was almost an order of magnitude less in April (Figs. 1 and 2). It appears as if there may be some non-ergosterol-containing microorganisms that have some importance, particularly in spring. Thus further studies comparing bacterial and fungal biomass and production on wood in these streams could clarify seasonal trends.

\section{Dissolved nutrients and wood biofilm activity}

Microbial biofilms on organic substrates are regulated by characteristics of the substrate (Gessner and Chauvet 1994) and environmental factors such as temperature and nutrient availability (Suberkropp and Chauvet 1995). Mellilo et al. (1982, 1983) found that decomposition rates of wood chips and leaf litter were inversely related to initial lignin : nitrogen ratios of the organic substrate. Additionally, the absolute amount of nitrogen that was ultimately immobilized by microbes was greater on substrates with lower lignin: nitrogen ratios (Melillo et al. 1983).

Previous research on the effect of dissolved nutrient concentrations on heterotrophic activity has focused primarily on the decomposition of leaf litter, indicating that microorganisms colonizing leaf litter obtained phosphorus from the water column (Elwood et al. 1981, Mulholland et al. 1984). More recently, it has also been shown that greater fungal biomass occurs in streams with higher nitrate concentration (Suberkropp 1995). Additionally, higher nutrient concentrations result in faster rates of leaf decomposition (Suberkropp and Chauvet 1995). In two other streams at Coweeta, Meyer and Johnson (1983) attributed higher rates of fungal sporulation, leaf decomposition, and microbial biomass to high streamwater nitrate concentration; our results agree with those results. We suggest that in addition to temperature, an interaction between stream dissolved nutrients and organic substrate availability controls the dynamics of heterotrophic processes. Increased availability of nutrients $(\mathrm{N}+\mathrm{P})$ as a result of a decrease in microbially colonized organic substrate in the exclusion stream may have contributed to the generally higher microbial activity on wood biofilms in this stream. Addition of nitrogen and phosphorus together increased microbial respiration and fungal biomass in the reference stream to levels found on control substrates in the exclusion stream (Fig. 6). In contrast, nutrient addition in the exclusion stream did not significantly increase respiration rates, indicating that the substrates in the exclusion stream were not nutrient limited at that time.

During both the autumn and spring experiments, woody debris was the only large organic substrate available for microbial colonization in the leaf exclusion stream. In the reference stream, leaves were abundant in autumn $\left(424 \mathrm{~g} / \mathrm{m}^{2}\right)$, yet leaf litter standing stocks had decreased by summer as a result of microbial decomposition and invertebrate feeding $\left(193 \mathrm{~g} / \mathrm{m}^{2}\right)(\mathrm{J}$. B. Wallace, University of Georgia, Athens, Georgia, unpublished data). The standing stock of microbially colonized organic substrate was twice as high in the autumn experiment compared to the spring experiment and therefore the allocation of nutrients to wood vs. leaf biofilms may have been very different. Previous research has attributed decreases in both $\mathrm{N}$ and $\mathrm{P}$ concentrations in stream water during autumn to microbial uptake (Mulholland et al. 1984, 1985, Mulholland and Rosemond 1992). Data from short-term nutrient releases in the study streams, conducted before and after the litter exclusion, have shown that nitrogen (as ammonia) and phosphorus (as SRP) uptake lengths are significantly shorter indicating higher nutrient retention in the reference stream (J. R. Webster et al., unpublished data). By summer, wood was the primary large particulate organic matter source in the reference stream; hence, more nutrients were available for microbial uptake per unit surface area of wood due to fewer leaves. This scenario was simulated year-round in the leaf exclusion stream.

The addition of a conservative tracer into each stream indicated multiple areas of groundwater input (i.e., upwelling) into both streams (Fig. 7). Water samples from upwelling areas showed higher concentrations of nitrogen and phosphorus relative to concentrations at the flume. In a stream without leaves (the reference stream in late spring/summer or the litter ex- 
clusion stream year-round), nutrients may be available over a larger streambed area due to a reduction in the surface area of microbially colonized organic matter. In contrast, when leaves and wood are present (e.g., autumn), zones of higher nutrient availability (i.e., upwellings) would not extend as far away from their input point. Increased surface area of microbially colonized organic matter may rapidly immobilize dissolved nutrients entering from groundwater inputs. Therefore, the high respiration rates seen in the exclusion stream year-round, and in the reference stream in spring, may represent the augmentation of microbial activity due to an increase in nutrient availability.

Our results show that the amount and spatial distribution of organic substrate (wood and leaves) in a stream may affect the interaction between nutrient concentrations and heterotrophic microbial activity. Past research in both terrestrial and aquatic systems conflicts regarding the possible role of $\mathrm{N}: \mathrm{P}$ ratios and absolute nutrient concentrations in controlling microbial production and decomposition of organic matter. Concentrations of dissolved inorganic nutrients in the study streams were very low (total inorganic nitrogen (TIN) $=10-13 \mu \mathrm{g} / \mathrm{L}$ and SRP $=1-3 \mu \mathrm{g} / \mathrm{L}$; Table 1$)$. Since small changes in concentration of either $\mathrm{N}$ or $\mathrm{P}$ can have large effects on $\mathrm{N}: \mathrm{P}$ ratios, predicting nutrient limitation by $\mathrm{N}: \mathrm{P}$ ratios in the study streams is tenuous. Molar N:P ratios in the two streams ranged from 29 in the leaf exclusion stream to 7 in the reference stream, despite changes in nutrient concentrations on the order of only a few micrograms per liter. Additionally, with such low concentrations of $\mathrm{N}$ and $\mathrm{P}$, the study streams are likely to shift between $\mathrm{N}$ and $\mathrm{P}$ limitation, both in time and space, as a result of very small changes in nutrient concentrations. The exclusion of leaf litter thus appears to make inorganic nitrogen more available, but with such low stream nutrient concentrations we might expect a colimitation by both $\mathrm{N}$ and $\mathrm{P}$ as was demonstrated by results from the nutrient-diffusing substrates (Fig. 6).

Our conclusion is that in the absence of nutrient immobilization by leaves, nutrients are more available for other heterotrophic processes. This conclusion is consistent with the higher biofilm activity and fungal biomass in the litter exclusion stream and our results from the nutrient addition experiment using diffusing substrates. There are alternative explanations for our results which we have not addressed experimentally. It may be that the presence of leaves inhibits microbial activity in the wood biofilm through leaching of tannins or other organic chemicals. Also, the presence of leaves increases hydraulic retention (J. R. Webster, Virginia Tech, Blacksburg, Virginia, unpublished data) and decreases water velocity, which may have an effect on wood biofilms either through nutrient delivery rates or dissolved oxygen gradients at the water-substrate interface. It is unlikely, however, that decomposing leaves would reduce overall dissolved oxygen levels in these shallow, turbulent streams.

\section{Summary}

The leaf exclusion stream is an experimentally manipulated "natural environment." Groundwater inputs may be less rapidly immobilized due to fewer microbially colonized substrates (i.e., no leaves in the stream), resulting in higher fungal biomass, microbial respiration, and extracellular enzyme activity in the exclusion stream. In the reference stream, biofilm activity on wood was limited by $\mathrm{N}$ and $\mathrm{P}$, and nutrients may have been more rapidly immobilized due to higher organic substrate surface area. In temperate forest streams, both wood and leaves are present, in different proportions, from October through May. The presence of leaves in these streams may affect microbial activity on other organic substrates (e.g., wood) through the immobilization of a limited supply of nutrients from overlying streamwater. In streams with low nutrient concentrations, like those at Coweeta, there is a potential competition for dissolved nutrients between wood and leaf biofilms as microbial decomposers on wood and leaves are both in need of nitrogen and phosphorus. Results from our studies imply that heterotrophs colonizing organic substrates may be competing with each other for necessary nutrients that may be in short supply, both in their substrate and in the overlying water column. This implies that in forested headwater streams, like those at Coweeta, a bottom-up control may be governing detrital dynamics and ultimately carbon cycling. In less shaded streams, where algal production is an important component of the ecosystem, autotrophs may compete with heterotrophs for nutrients, again implying bottom-up control on ecosystem function.

\section{ACKNOWLEDGMENTS}

This research was in partial fulfillment of a Ph.D. degree in the Biology Department at Virginia Tech for J. L. Tank. This research benefited enormously from discussions with $\mathrm{E}$. F. Benfield, R. L. Sinsabaugh, J. H. Harding, M. J. Winterbourn, and O. K. Miller. We are grateful to N. B. Grimm and two anonymous reviewers for valuable suggestions that improved the paper. J. B. Wallace and S. L. Eggert provided long-term data sets for stream temperature, organic matter standing stocks, and water chemistry from the Coweeta Litter Exclusion Project. P. Franchini and R. L. Sinsabaugh graciously taught me the fungal biomass and enzyme techniques. L. Martin and B. Greyson assisted with laboratory and field work. This research was supported by a National Science Foundation Dissertation Improvement Grant, DEB-9423518 and additional funding was provided by the Coweeta Litter Exclusion Project, NSF Grant DEB-9207498 to J. B. Wallace, J. L. Meyer, and J. R. Webster.

\section{Literature Cited}

APHA. 1989. Standard methods for the examination of water and wastewater. American Public Health Association, Washington, D. C., USA.

Aumen, N. G., P. J. Bottomley, G. M. Ward, and S. V. Gregory. 1983. Microbial decomposition of wood in streams: distribution of microflora and factors affecting ${ }^{14} \mathrm{C}$ ligno- 
cellulose mineralization. Applied Environmental Microbiology 46:1409-1416.

Baldy, V., M. O. Gessner, and E. Chauvet. 1995. Bacteria, fungi and the breakdown of leaf litter in a large river. Oikos 74:93-102.

Cuffney, T. F., J. B. Wallace, and G. J. Lugthart. 1990. Experimental evidence quantifying the role of benthic invertebrates in organic matter dynamics of headwater streams. Freshwater Biology 23:281-289.

Elwood, J. W., J. D. Newbold, A. F. Trimble, and R. W. Stark 1981. The limiting role of phosphorus in a woodland stream ecosystem: effects of P enrichment on leaf decomposition and primary producers. Ecology 62:146-158.

Findlay, S. G., and T. L. Arsuffi. 1989. Microbial growth and detritus transformations during decomposition of leaf litter in a stream. Freshwater Biology 21:261-269.

Gessner, M. O., and E. Chauvet. 1994. Importance of stream microfungi controlling breakdown rates of leaf litter. Ecology 75:1807-1817.

Golladay, S. W., and R. L. Sinsabaugh. 1991. Biofilm development on leaf and wood surfaces in a boreal river. Freshwater Biology 25:437-450.

Golladay, S. W., and J. R. Webster. 1988. Effects of clearcut logging on wood breakdown in Appalachian mountain streams. American Midland Naturalist 119:143-154.

Grimm, N. B., and S. G. Fisher. 1986. Nitrogen limitation in a Sonoran desert stream. Journal of the North American Benthological Society 5:2-15.

Harmon, M. E., J. F. Franklin, F. J. Swanson, P. Sollins, S. V. Gregory, J. D. Lattin, N. H. Anderson, S. P. Cline, N. G. Aumen, J. R. Sedell, G. W. Lienkaemper, K. Cromack, Jr., and K. W. Cummins. 1986. Ecology of course woody debris in temperate ecosystems. Advances in Ecological Research 15:133-302.

Howarth, R. W., and S. G. Fisher. 1976. Carbon, nitrogen, and phosphorus dynamics during leaf decay in nutrientenriched stream microecosystems. Freshwater Biology 6: 221-228.

Hynes, H. B. N., and N. K. Kaushik. 1969. The relationship between dissolved nutrient salts and protein production in submerged autumnal leaves. Internationale Vereinigung für theoretische und angewandte Limnologie, Verhandlungen 17:95-103.

Melillo, J. M., J. D. Aber, and J. F. Muratore. 1982. Nitrogen and lignin control of hardwood leaf litter decomposition dynamics. Ecology 63:621-626.

Melillo, J. M., R. J. Naiman, J. D. Aber, and K. N. Eshleman 1983. The influence of substrate quality and stream size on wood decomposition dynamics. Oecologia 58:281-285.

Meyer, J. L., and C. Johnson. 1983. The influence of elevated nitrate concentration on rate of leaf decomposition in a stream. Freshwater Biology 13:177-183.

Morris, D. P., and W. M. Lewis, Jr. 1992. Nutrient limitation of bacterioplankton growth in Lake Dillon, Colorado. Limnology and Oceanography 37:1179-1192.

Mulholland, P. J., J. W. Elwood, J. D. Newbold, J. R. Webster, L. A. Ferren, and R. E. Perkins. 1984. Phosphorus uptake by decomposing leaf detritus: effect of microbial biomass and activity. Internationale Vereinigung für theoretische und angewandte Limnologie, Verhandlungen 22:18991905.

Mulholland, P. J., J. D. Newbold, J. W. Elwood, L. A. Ferren, and J. R. Webster. 1985. Phosphorus spiraling in a woodland stream: seasonal variations. Ecology 66:1012-1023.

Mulholland, P. J., and A. D. Rosemond. 1992. Periphyton response to longitudinal nutrient depletion in a woodland stream: evidence of upstream-downstream linkage. Journal of the North American Benthological Society 11:405-419.

Newbold, J. D., J. W. Elwood, M. S. Schulze, R. W. Stark, and J. C. Barmeier. 1983. Continuous ammonium enrich- ment of a woodland stream: uptake kinetics, leaf decomposition, and nitrification. Freshwater Biology 13:193-204.

Newell, S. Y., T. L. Arsuffi, and R. D. Fallon. 1988. Fundamental procedures for determining ergosterol content of decaying plant material by liquid chromatography. Applied and Environmental Microbiology 54:1876-1869.

Petersen, R. C., and K. W. Cummins. 1974. Leaf processing in a woodland stream. Freshwater Biology 4:343-368.

Peterson, B. J., L. Deegan, J. Helfrich, J. E. Hobbie, M. Hullar, B. Moller, T. E. Ford, A. Hershey, A. Hiltner, G. Kipphut, M. A. Lock, D. M. Fiebig, V. McKinley, M. C. Miller, J. R. Vestal, R. Ventullo, and G. Volk. 1993. Biological responses of a tundra river to fertilization. Ecology 74:653-672.

Peterson, B. J., J. E. Hobbie, A. E. Hershey, M. A. Lock, T. E. Ford, J. R. Vestal, J. L. McKinley, M. A. J. Hullar, M. C. Miller, R. M. Ventullo, and G. S. Volk. 1985. Transformation of a tundra river from heterotrophy to autotrophy by addition of phosphorus. Science 229:1383-1386.

Pringle, C. M. 1987. Effects of water and substratum nutrient supplies on lotic periphyton growth: an integrated bioassay. Canadian Journal of Fisheries and Aquatic Sciences 44: 619-629.

Rosemond, A. D., P. J. Mulholland, and J. W. Elwood. 1993. Top-down and bottom-up control of stream periphyton: effects of nutrients and herbivores. Ecology 74:1264-1280.

Schindler, D. W. 1977. Evolution of phosphorus limitation in lakes. Science 195:260-262.

Shearer, C. A., and S. B. Von Bodman. 1983. Patterns of occurrence of ascomycetes associated with decomposing twigs in a midwestern stream. Mycologia 75:518-530.

Sinsabaugh, R. L., S. W. Golladay, and A. E. Linkins. 1991. Comparison of epilithic and epixylic biofilm development in a boreal river. Freshwater Biology 25:179-187.

Stream Solute Workshop. 1990. Concepts and methods for assessing solute dynamics in stream ecosystems. Journal of the North American Benthological Society 9:95-119.

Suberkropp, K. 1984. Effect of temperature on seasonal occurrence of aquatic hyphomycetes. Transactions of the British Mycological Society 82:53-62.

1995. The influence of nutrients on fungal growth, productivity, and sporulation during leaf breakdown in streams. Canadian Journal of Botany 73 (Supplement 1): S1361-S1369.

Suberkropp, K., and E. Chauvet. 1995. Regulation of leaf breakdown by fungi in streams: influences of water chemistry. Ecology 76:1433-1445.

Tank, J. L., J. R. Webster, and E. F. Benfield. 1993. Microbial respiration on decaying leaves and sticks in a southern Appalachian stream. Journal of the North American Benthological Society 12:394-405.

Tank, J. L., and M. J. Winterbourn. 1995. Biofilm development and invertebrate colonization of wood in four New Zealand streams of contrasting $\mathrm{pH}$. Freshwater Biology 34: 303-315.

Tank, J. L., and M. J. Winterbourn. 1996. Heterotrophic activity and invertebrate colonization of wood in a New Zealand forest stream. New Zealand Journal of Marine and Freshwater Research 30:271-280.

Triska, F. J., and K. Cromack. 1980. The role of wood debris in forests and streams. Pages 171-190 in R. H. Waring, editor. Forests: fresh perspectives from ecosystem analysis. Oregon State University Press, Corvallis, Oregon, USA.

Triska, F. J., V. C. Kennedy, R. J. Avanzino, G. W. Zellweger, and K. E. Bencas. 1989. Retention and transport of nutrients in a third-order stream in northwestern California: Hyporheic processes. Ecology 70:1893-1905.

Triska, F. J., and J. R. Sedell. 1976. Decomposition of four species of leaf litter in response to nitrate manipulation. Ecology 57:783-792. 
Umbreit, W. W., R. H. Burris, and J. F. Stauffer. 1964. Manometric techniques. Burgess, Minneapolis, Minnesota, USA.

Wallace, J. B., T. F. Cuffney, S. L. Eggert, and M. R. Whiles. 1997a. Stream organic matter inputs, storage, and export for Catchment 55 at Coweeta. Pages 67-74 in J. R. Webster and J. L. Meyer, editors. Stream organic matter budgets. Journal of the North American Benthlogical Society 16:3161.

Wallace, J. B., S. L. Eggert, J. L. Meyer, and J. R. Webster. 1997b. Multiple trophic levels of a forest stream linked to terrestrial litter inputs. Science 277:102-104.
Webster, J. R., and E. F. Benfield. 1986. Vascular plant breakdown in freshwater ecosystems. Annual Review of Ecology and Systematics 17:567-594.

Webster, J. R., and T. P. Ehrman. 1996. Solute Dynamics. Pages 145-160 in F. R. Hauer and G. A. Lamberti, editors. Methods in stream ecology. Academic Press, San Diego, California, USA.

Wetzel, R. G. 1983. Limnology. Saunders, Philadelphia, Pennsylvania, USA.

Winterbourn, M. J. 1990. Interactions among nutrients, algae, and invertebrates in a New Zealand mountain stream. Freshwater Biology 23:463-474. 